\title{
THE INVOLUTION OF CUTANEOUS XANTHOMATA CAUSED BY DIETS LOW IN CALORIES
}

\author{
By A. C. CURTIS, U. J. WILE AND H. C. ECKSTEIN
}

(From the Departments of Internal Medicine, Dermatology and Physiological Chemistry, University of Michigan Medical School, Ann Arbor)

(Received for publication November 2, 1928)

Since the demonstration of cholesterol crystals in xanthomata by Bazin (1) in 1869 and the subsequent finding of a hypercholesterolemia by Chauffard and Laroche (2), cutaneous xanthomata have been considered cholesterol tumors. It has been pointed out by Wile, Eckstein, and Curtis (3) that xanthomatous tumors do not have as much cholesterol in them as does the surrounding skin and that their presence does not necessarily depend upon a lipemia or a hypercholesterolemia. In this same study it was demonstrated that not more than 11 per cent of the tumors was neutral fat and 16 per cent of this was cholesterol. Major (4) has shown that xanthomatous nodules consist of neutral fat, fatty acids, lipoids, and cholesterol. It is a common observation that xanthomata associated with hyperglycemia are often seen in obese individuals and as these tumors consist of neutral fat, fatty acids, lipoids, and cholesterol they may represent deposits of fat in the skin serving the same purpose as other fat depots in the body. If such a premise be true these cutaneous deposits of fat should respond to dietary measures as other fat depots do. Such was shown in our first paper (3) to be true, at least in part. In order to investigate this hypothesis further we have studied three patients with xanthomata. The first two patients were sisters who developed xanthomatous lesions within six months of each other without an associated diabetes. The third patient had a severe form of cutaneous xanthomata and diabetes mellitus. All patients had a lipemia.

\section{CASE HISTORIES}

Case 1. K. L., female, age 8, came to the hospital complaining of an eruption which began $1 \frac{1}{2}$ years ago as a glass pin head size yellowish hypertrophic growth on 


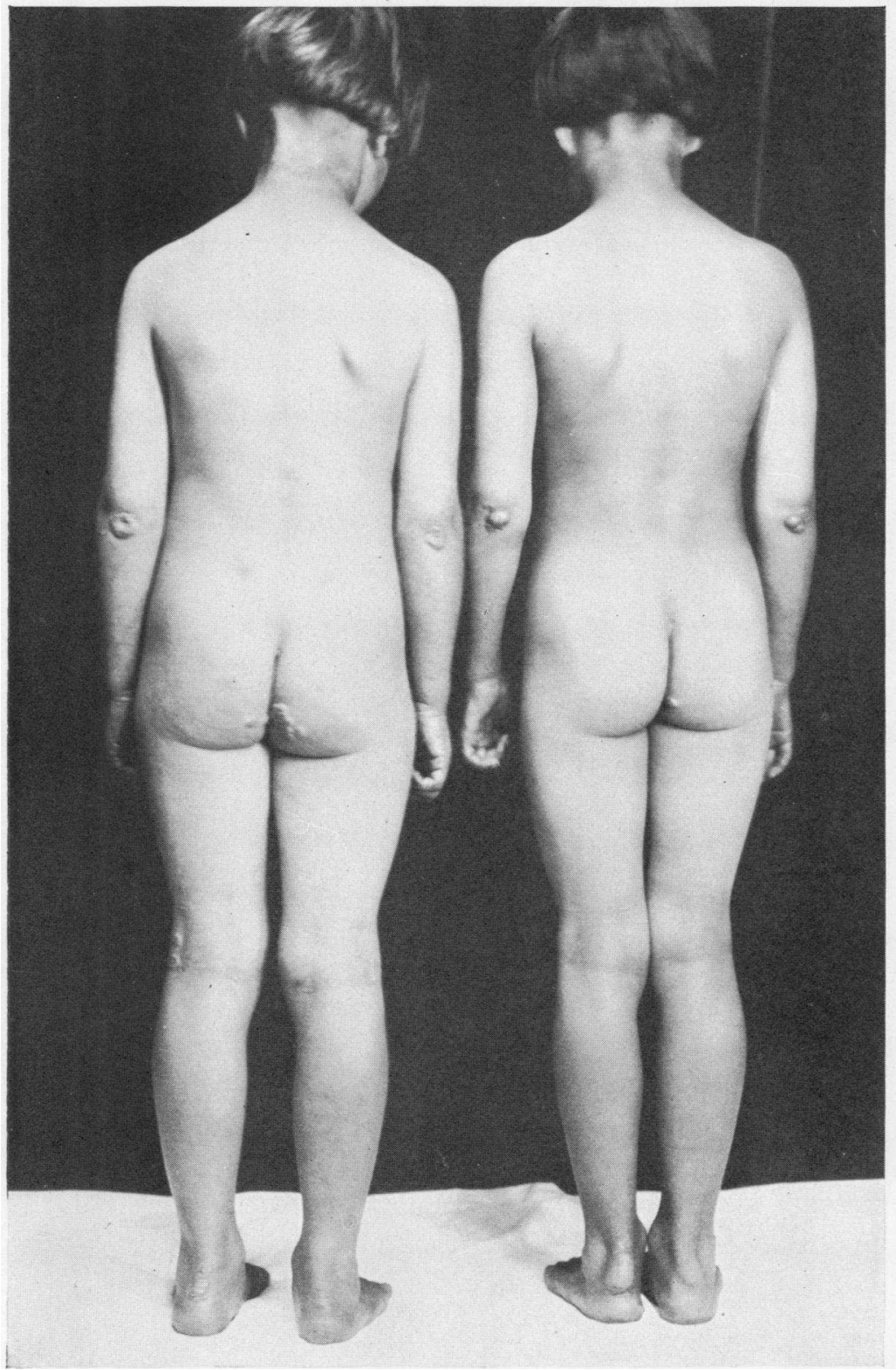

Fig. 1. Case 1, K. L., and Case 2, M. L., Showing the Distribution of the Xanthomatous Lesions and Their Nodular Character 
the dorsal surface of both elbows. The nodules were yellow in color and painless. They slowly increased in size and in number until they involved all extremities and the trunk. Except for measles, mumps, whooping cough, and chickenpox, her past history is essentially negative. Neither has she had any symptoms referable to diabetes mellitus nor has there been any family history of the disease. On the anterior aspect of the body she presented three small lesions on the outer aspect of the right knee and two small lesions on the upper outer aspect of the left knee. These nodules varied approximately from 1 to $10 \mathrm{~mm}$. in diameter. They were sharply elevated from the surrounding skin, orange yellow in color, and firm to palpation. On the posterior aspect of the body the lesions were located over the elbows, in the gluteal cleft, and over both tendo-Achilles. The lesions for the most part were made up of groups of nodules varying in diameter from 1 to $15 \mathrm{~mm}$. They were orange yellow in color, sharply elevated from the surrounding skin, and firm to palpation. (See fig. 1.) Clinical diagnosis: xanthoma tuberosum. Pathological diagnosis: xanthoma tuberosum.

Case 2. M. L., age 7, a sister of K. L. came to the clinic complaining of a small nodular eruption which had begun two years ago on the dorsal aspect of both elbows. The lesions slowly increased in size and in distribution until they were present over all extremities and the trunk. Her past history is negative except for measles, mumps, chickenpox, and whooping cough. No symptoms of diabetes mellitus were present.

On the anterior aspect of the body she presented two small lesions on either side of the glabella which were approximately 1 to $10 \mathrm{~mm}$. in diameter. On the volar surface of the right wrist were two lesions; one approximately $15 \mathrm{~mm}$. and one approximately $2 \mathrm{~mm}$. in diameter. Over the outer aspect of both knees there were similar lesions slightly larger than those of the arms. Most of the lesions were orange yellow in color, sharply raised from the surrounding skin and firm to palpation. Over the posterior surface there were lesions on the neck which were verrucous and linear appearing something like a naevus. Over the elbows and in the popliteal space the lesions were made up of a confluence of smaller lesions varying in size from approximately 10 to $50 \mathrm{~mm}$. in diameter. Over the lower aspects of the tendo-Achilles the lesions were somewhat smaller. (See fig. 1.) Clinical diagnosis: xanthoma tuberosum. Pathological diagnosis: xanthoma tuberosum.

Case 3. B. B., male, age 42 , came to the hospital because of an extensive eruption all over his body. Five years previously he noticed a small papular and nodular eruption on his shoulders and the extensor surfaces of his arms. The lesions were yellow, moderately firm, and discrete. They rapidly spread until they involved the whole body with predilection for the buttocks, extensor surfaces of the arms and legs. Since then the lesions have persisted and are painful when traumatized. 
The patient was an obese male (193 pounds) who presented over the trunk, elbows, knees, buttocks, and backs of the hands large numbers of typical tuberous xanthomatous lesions. The older lesions were quite hard and tender on pressure. The color of the lesions was a chamois yellow. The urine showed a $4+$ sugar and the blood a definite hyperglycemia and lipemia.

Diagnosis: diabetes mellitus, obesity xanthoma tuberosum.

\section{METHODS}

Case 1, K. L., and case 2, M. L., were hospitalized July 2, 1928, and placed on a diet consisting of 70 grams of protein, 150 grams of fat, and 100 grams of carbohydrate. Two basal metabolism determinations were done on each patient on successive days. The 24 hour basal calories were then calculated for both case $1, \mathrm{~K}$. L., and case 2, M. L., from Sanford's Tables for their height, weight, age, sex, and basal metabolism. These determinations were followed by a glucose tolerance test which was repeated at the conclusion of the low calorie diet periods. Daily weights were taken on each patient before breakfast clothed only in the standard hospital night-grown. Specimens for blood lipoid determinations were drawn at the same time the first glucose tolerance test was done; 10 days later, and 30 days later. Routine daily urines were done. Case 3, B. B., was placed on four different types of diets. The first was the usual series of diets used by this hospital to determine the tolerance for glucose in diabetic patients; the second a definite reduction diet; the third a high fat and high calorie diet; and the fourth a maintenance diet. Glucose tolerance tests were done at the beginning of the experiment and at its end. Daily urines were examined during all periods except the second. Only one urine analysis was obtained at the end of this period. Changes in his weight were recorded at the end of each dietary period.

Four blood lipoid determinations were made; two on separate uncontrolled diets; one while on the high calorie diet, and one while on the maintenance diet.

\section{DATA}

It will be seen from table 1 , that case $1, \mathrm{~K}$. L. and case $2, \mathrm{M}$. L., were placed on diets of 2030 calories. The 24 -hour basal calories of case $1, \mathrm{~K}$. L., were determined on successive days to be 1050 and 1090 calories. The 24-hour basal calories of case 2, M. L., were determined 
on successive days to be 980 and 960 calories. It is evident then that this diet was well above their maintainence calories. They remained on this diet for 6 days. A slight increase in the firmness of the tumors and the depth of their color was noted. No marked change in weight occurred. For 8 days following this they were placed on diets of 50 grams of protein, 80 grams of fat, and 50 grams of carbohy-

TABLE 1

The effect of various diets on xanthomatous lesions. Case 1, K. L., and Case 2, M. L.

\begin{tabular}{|c|c|c|c|c|c|c|c|c|c|}
\hline \multirow[b]{2}{*}{ Date } & \multicolumn{4}{|c|}{ Diet } & \multicolumn{2}{|c|}{ Weight } & \multicolumn{2}{|c|}{ Blood fat } & \multirow[b]{2}{*}{ Effect on tumors } \\
\hline & 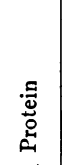 & 总 & 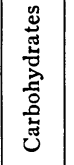 & 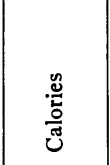 & $\begin{array}{l}\dot{\dot{u}} \\
\dot{u} \\
\dot{\vec{u}} \\
\dot{\tilde{J}} \\
\dot{u}\end{array}$ & $\begin{array}{l}\dot{j} \\
\dot{\Sigma} \\
\dot{N} \\
\tilde{u} \\
\tilde{u}\end{array}$ & 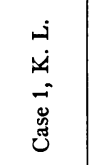 & $\begin{array}{l}\dot{j} \\
\dot{\Sigma} \\
\dot{j} \\
\dot{\tilde{J}} \\
\tilde{u} \\
\tilde{J}\end{array}$ & \\
\hline & $g m$ & $g m$. & $g m$. & & lbs. & lbs. & $\begin{array}{c}\mathrm{mgm} . \\
\text { per. } \\
100 \mathrm{cc} .\end{array}$ & $\begin{array}{c}\mathrm{mgm} . \\
\text { per } \\
100 \mathrm{cc} .\end{array}$ & \\
\hline July 3-9 & 70 & 150 & $100^{*}$ & 2,030 & \begin{tabular}{|l|}
$53 \frac{3}{4}$ \\
$53 \frac{1}{2}$
\end{tabular} & 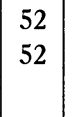 & 1,383 & 1,330 & $\begin{array}{l}\text { Increased in hardness. } \\
\text { Color deepened to } \\
\text { orange yellow }\end{array}$ \\
\hline July $10-17$ & 50 & 80 & $50 *$ & 1,172 & \begin{tabular}{|l|}
$53 \frac{1}{2}$ \\
$53 \frac{1}{2}$
\end{tabular} & $\begin{array}{l}52 \\
52 \frac{1}{4}\end{array}$ & 1,340 & 1,350 & No change \\
\hline July $18-26$ & 40 & 20 & $40 *$ & 500 & \begin{tabular}{|l|}
$53 \frac{1}{4}$ \\
$52 \frac{1}{2}$
\end{tabular} & \begin{tabular}{|l|}
$51 \frac{1}{2}$ \\
$51 \frac{1}{4}$
\end{tabular} & & & No change \\
\hline $\begin{array}{l}\text { July } 27- \\
\quad \text { August } 6\end{array}$ & 35 & 13 & 39 & 413 & \begin{tabular}{|l|}
$52 \frac{1}{4}$ \\
$48 \frac{1}{2}$
\end{tabular} & \begin{tabular}{|l|}
$51 \frac{1}{4}$ \\
$48 \frac{1}{2}$
\end{tabular} & 1,183 & 1,030 & Beginning involution \\
\hline August 7-10 & Hor & use die & & $\begin{array}{r}? 2,500- \\
3,000\end{array}$ & $\begin{array}{l}48 \frac{1}{2} \\
55\end{array}$ & $\begin{array}{l}48 \\
52 \frac{1}{4}\end{array}$ & & & $\begin{array}{l}\text { Increase in size, firm- } \\
\text { ness, and depth of } \\
\text { color of all tumors }\end{array}$ \\
\hline
\end{tabular}

* Plus an unknown number of calories obtained surreptitiously from other patients.

drate with a total of 1120 calories. No effect was observed on the tumors and no change occurred in the patients' weight. We felt that this diet was too near their maintainence calories, even though they were up and about the ward, so they were placed on diets of 40 grams of protein, 20 grams of fat, and 40 grams of carbohydrate having a total of 500 calories. Two hours of exercise in the gymnasium was 
done daily. One day after the diet was begun it was found that both patients had been given peanuts by their family and that during their wanderings about the ward, patients had given them candy, fruit, and food from the hospital trays. The patients hence were strictly con-

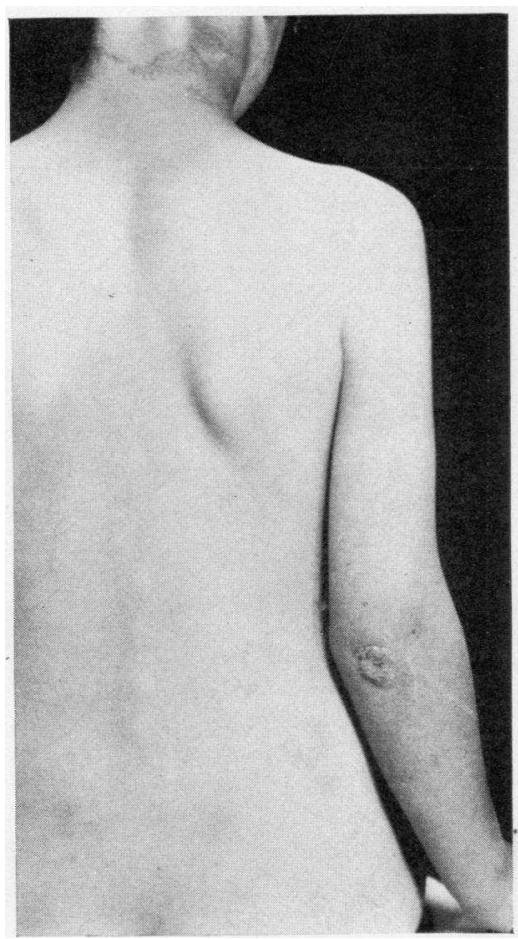

Fig. 2, $A$

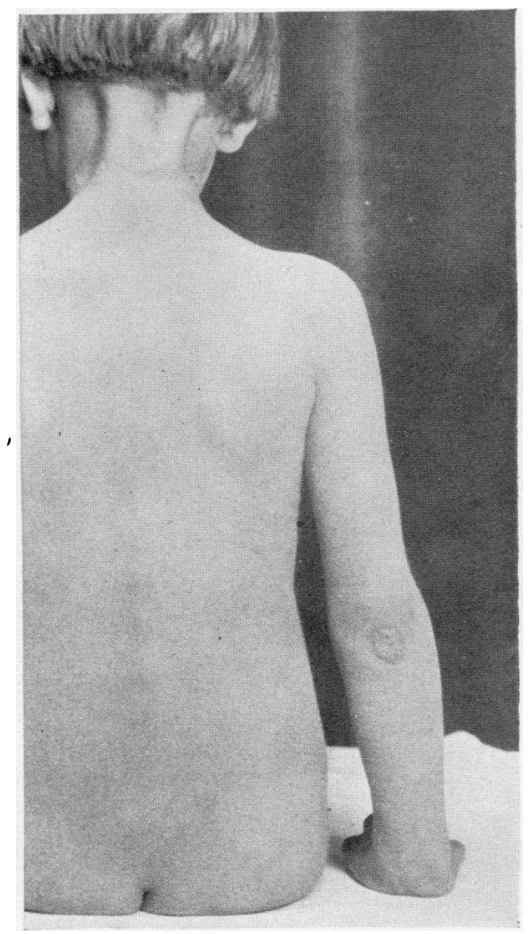

FIG. 2, $B$

Fig. 2. (A) Case 1, K. L., Showing the Size and Nodular Character of the Xanthomatous Lesion on the Right Elbow Before Treatment. (B) Case 1, K. L., Showing the Decrease in Size and Flattening of the Surface of the Lesion After a Short Period of Treatment

fined to their rooms and for the first time a definite loss of weight occurred. Nine days later their diets were further reduced to 35 grams of protein, 13 grams of fat, and 39 grams of carbohydrate, having a total of 413 calories. A rapid loss of weight occurred. With the beginning of the weight loss there was also noted a definite softening of the 
tumors. The orange yellow color began to fade and a pink hue developed. (See fig. 2 and 3.) It will also be seen from table 1 that the blood lipoids which had formerly been high, now showed a definite decrease.

Unfortunately at this point we were notified that the children could only remain in the hospital 5 days longer so they were immediately put on house diets. Their weight increased rapidly to a level greater

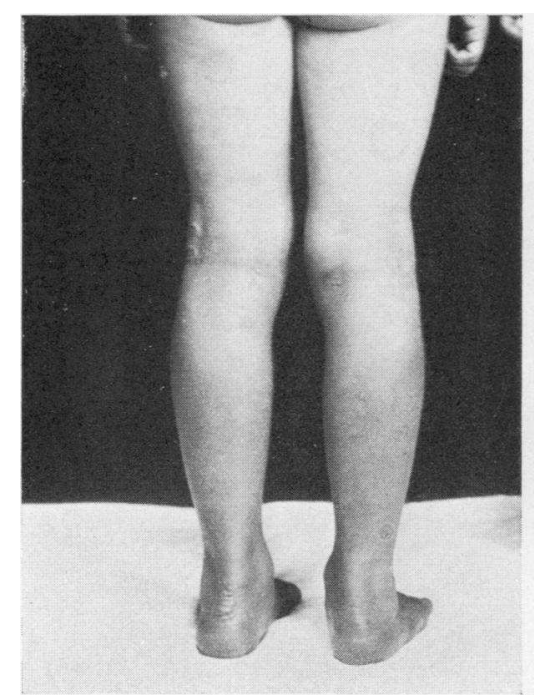

Fig. 3, $A$

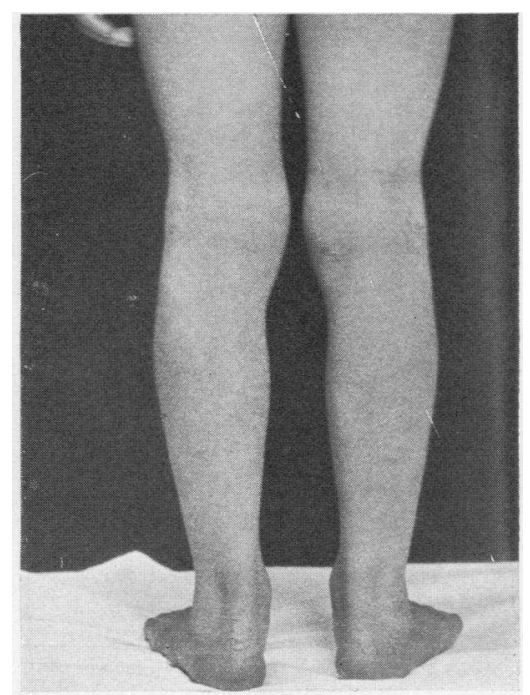

FIG. 3, $B$

Fig. 3. Case 1, K. L., (A) Before Treatment and (B) After Treatment

Note the decrease in the size and fullness of the nodular eruption on the margins of the right and left popliteal spaces and the left heel.

than at their entrance. The lesions again became firm and the orange yellow hue returned.

The urine examinations throughout the experiment were negative except for numerous fat droplets which disappeared while on the last low calorie diet. The glucose tolerance curves (see fig. 4) from these patients suggest an inability to tolerate large amounts of glucose.

It will be seen from table 2 that case 3, B. B., a mild diabetic, when placed on a series of desugarization diets in which the fat was constant and the calories were increased by the addition of glucose, experienced 
an involution of his tumors and a loss of weight. This dietary procedure was followed by a diet consisting of 50 grams of protein, 50 grams of fat, and 200 grams of carbohydrate. While on this diet he lost 17 pounds in 30 days and his tumors continued to involute. $\mathrm{He}$ was then placed on a diet high in calories and fat for 30 days. This diet consisted of 55 grams of protein, 210 grams of fat, and 300 grams

\section{MGS \\ $100 \mathrm{cc}$ 's 450}

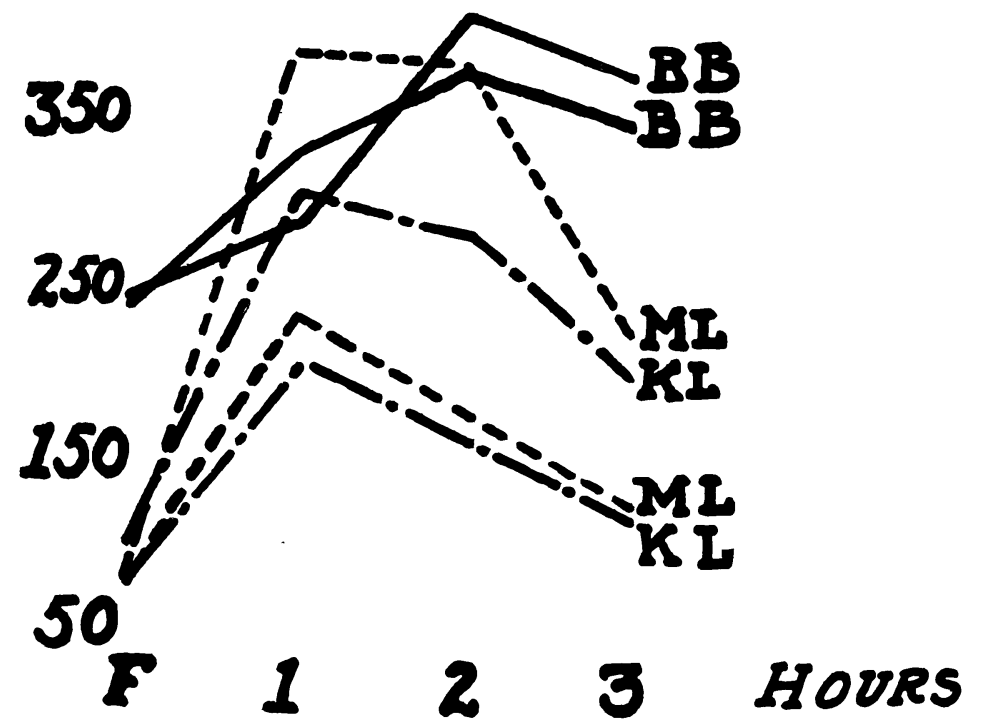

Fig. 4. The Trpical Diabetic Intolerance for Gllcose of Case 3, B. B. and the Atrpical Ceries of Cases 1, K. L., avd 2, M. L., Are

Show in This Figere

of carbohydrate with a total of 3310 calories. During this period he gained 8 pounds weight and had a reappearance of all his tumors. He also had a glycosuria and acetonuria. Following this he was given a maintainence diet consisting of 55 grams of protein, 210 grams of fat and 100 grams of carbohydrate with a total of 2510 calories. It will be noted that the fat of this diet is the same as the former diet but the 
TABLE 2

Effect of diets high in calories and low in calories on xanthomatous lesions. Case 3, B. B.

\begin{tabular}{|c|c|c|c|c|c|c|c|}
\hline \multicolumn{4}{|c|}{ Diets } & \multirow{2}{*}{$\begin{array}{c}\text { Dura- } \\
\text { tion } \\
\text { of } \\
\text { diet }\end{array}$} & \multirow{2}{*}{ Weight, gain or loss } & \multirow{2}{*}{$\underset{\text { fat }}{\text { Blood }}$} & \multirow{2}{*}{ Effect on tumors } \\
\hline Protein & Fat & $\left|\begin{array}{c}\text { Carbo- } \\
\text { hydrates }\end{array}\right|$ & $\begin{array}{c}\text { Calo- } \\
\text { ries }\end{array}$ & & & & \\
\hline grams & grams & grams & & days & & $\begin{array}{c}\mathrm{mgm} . \\
\text { per } \\
100 \mathrm{cc.}\end{array}$ & \\
\hline \multicolumn{3}{|c|}{ House diet } & ? & & Gain & 2,275 & \\
\hline 55 & 210 & 35 & 2,240 & 3 & & 2,215 & Beginning involution \\
\hline 55 & 210 & 50 & 2,300 & 3 & & & Beginning involution \\
\hline 55 & 210 & 100 & 2,500 & 3 & Loss of 12 pounds & & Beginning involution \\
\hline 55 & 210 & 150 & 2,700 & 3 & & & Beginning involution \\
\hline 55 & 210 & 175 & 2,800 & 3 & & & Beginning involution \\
\hline 50 & 50 & 200 & 1,450 & 30 & Loss of 17 pounds & & Marked involution \\
\hline 55 & 210 & 300 & 3,310 & 30 & Gain of 8 pounds & 2,416 & Reappearance \\
\hline 55 & 210 & 100 & 2,510 & 45 & $\begin{array}{l}\text { Little change in } \\
\text { weight }\end{array}$ & 1,175 & Complete involution \\
\hline 55 & 210 & 100 & 2,510 & 180 & $\begin{array}{l}\text { Little change in } \\
\text { weight }\end{array}$ & & $\begin{array}{l}\text { Complete involution; } \\
\text { all tumors replaced by } \\
\text { scar tissue }\end{array}$ \\
\hline \multicolumn{3}{|c|}{ Unmeasured diet } & ? & 30 & Gained 5 pounds & 2,225 & $\begin{array}{l}\text { Reappearance of three } \\
\text { tumors }\end{array}$ \\
\hline
\end{tabular}

TABLE 3

Influence of fat on blood lipoids

\begin{tabular}{l|l|l}
\hline & Blood fat & Increase \\
\hline
\end{tabular}

Patient B. B. case 3

\begin{tabular}{|c|c|c|}
\hline Fasting & $\begin{array}{c}\text { mgm. per } 100 \mathrm{cc} . \\
2,300\end{array}$ & per cent \\
\hline 2 hours after $100 \mathrm{cc}$. of olive oil. . & 2,630 & 14 \\
\hline 4 hours after $100 \mathrm{cc}$. of olive oil. & 2,769 & 16 \\
\hline 6 hours after $100 \mathrm{cc}$. of olive oil. & 2,337 & 2 \\
\hline
\end{tabular}

Patient S, normal blood fat

\begin{tabular}{|c|c|c|}
\hline 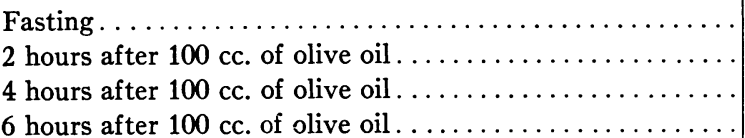 & $\begin{array}{l}439 \\
467 \\
600 \\
508\end{array}$ & $\begin{array}{r}6 \\
37 \\
13\end{array}$ \\
\hline
\end{tabular}


calories have been reduced by a decrease in the carbohydrate. At the end of 45 days his tumors had almost disappeared. (See fig. 5.) There was also a decrease of 50 per cent in his lipemia. (See table 2). He was discharged on 55 grams of protein, 210 grams of fat, and 100

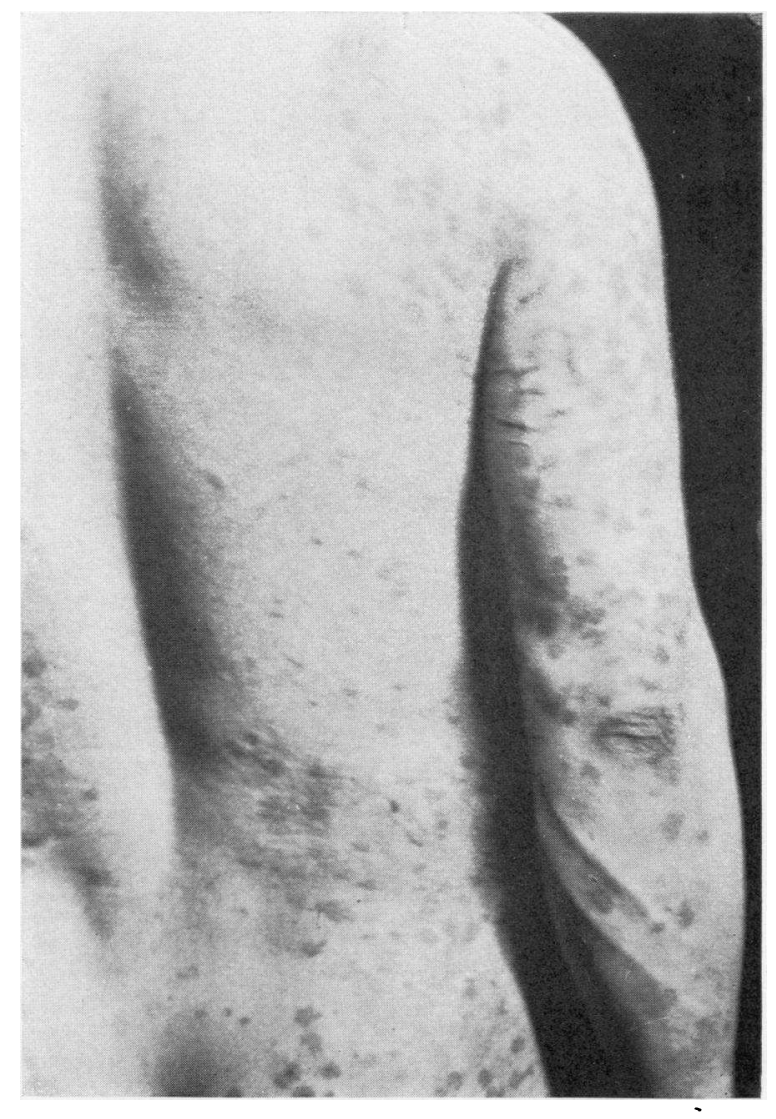

FIG. 5, $A$

Fig. 5. Case 3, B. B., Showing ( $A$ ) the Distribution of the Xanthomatous Lesions and Their Verrucous Character about the Waist Line. ( $B$ Shows the Result After 45 Days on a Diet of Maintenance Calories, and $(C)$ afrer 180 Days on a Maintenance Calorie Diet

The areas shown in $(C)$ are all scar tissue. No real xanthomatous lesions remain. 

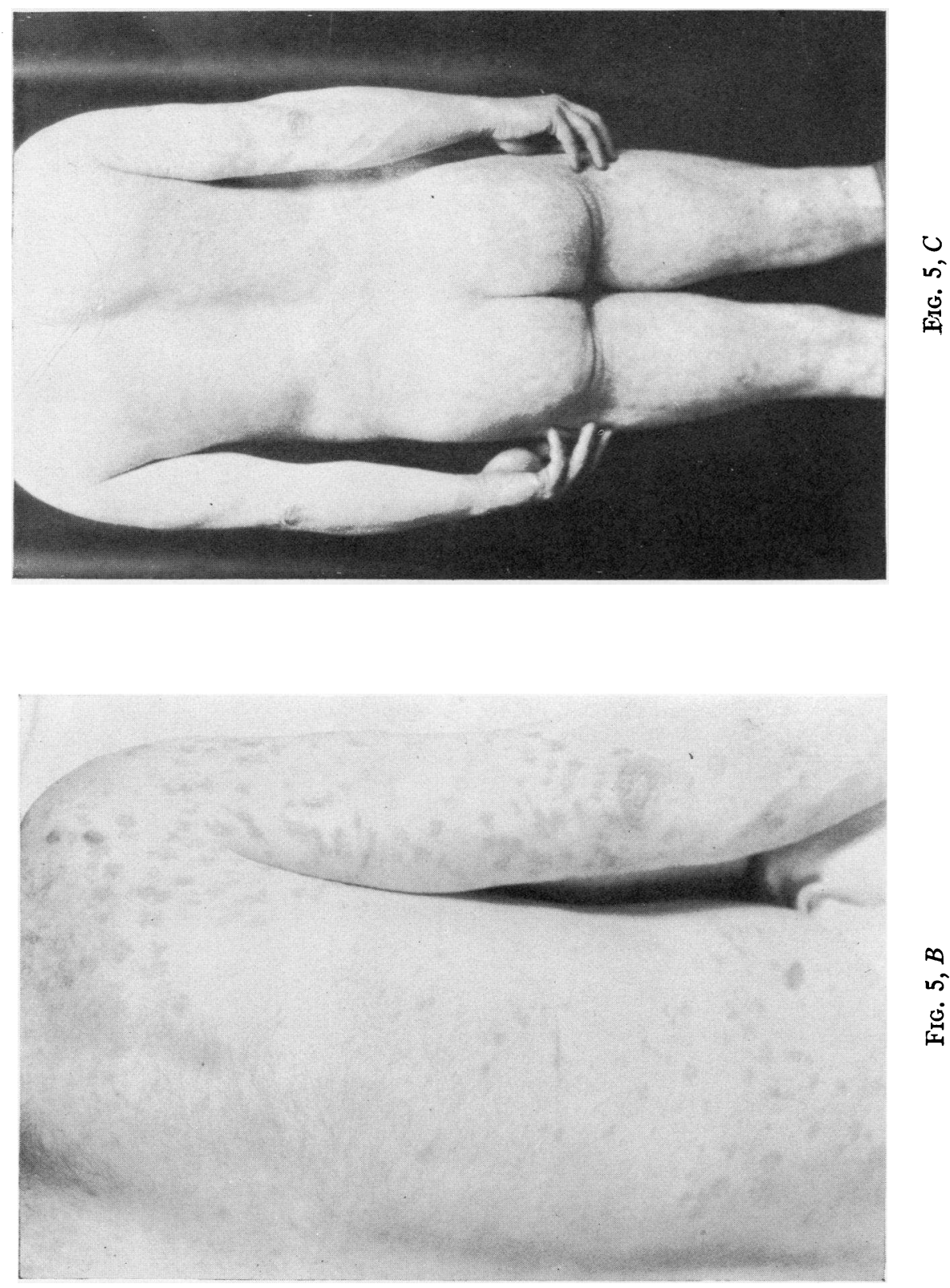
grams of carbohydrate. He followed this diet quite well for about 5 months without return of his tumors. He then broke his dietary régime frequently and on September 26th reappeared in the clinic having gained 5 pounds weight. On the dorsal surface of the right foot were two small xanthomatous nodules and on the extensor surface of the left forearm was a third. A specimen of blood taken at this time showed a creamy serum and his blood fats were again $2225 \mathrm{mgm}$. per cent.

Table 3 shows the per cent increase of blood fat in this patient following a meal of 100 grams of olive oil which compares favorably with the normal subject (3). This is in accord with the work of Blatherwick (5) and Marsh and Waller (6) who have shown that ingested fat has no relation to the lipemia which is found in diabetics.

Our experiences with cases 1, K. L., and 2, M. L., show that reduction diets cause an involution of the tumors. Case 3, B. B., shows that the involution of the tumors is influenced by a reduction of calories rather than a decrease in dietary fat, for when the fat of the diet was 210 grams and the calories 3310 the tumors reappeared whereas when the fat of the diet was 210 grams but the calories were 2510 the tumors disappeared.

\section{CONCLUSIONS}

1. Diets, low in calories, cause involution of xanthomatous lesions, whereas overnutrition causes their reappearance.

2. In patients with lipemia there seems to be a relation between the decrease in the blood fat and the involution of the xanthomatous tumors.

3. Neither is the lipemia, nor are the tumors affected by the fat of the diet except insofar as the fat is a source of calories.

4. The relation between ingested calories and the blood fat level is not known.

\section{BIBLIOGRAPHY}

1. Bazin, quoted by Hillairet, M., Bull. de L'Acad. de Med. 1878, series 2; vii, 1166. Vitiligoidea-Xanthelasma-Xanthoma.

2. Chauffard, A., and Laroche, G., La Sem. Med. 1910, xxx, 241. Pathogénie du xanthélasma. 
3. Wile, U. J., Eckstein, H. C., and Curtis, A. C., Arch. Derm. Syph. 1929, xix, 35. Lipid Studies in Xanthoma.

4. Major, R. H., Bull. Johns Hopkins Hosp. 1924, xxxv, 27. Xanthoma Diabeticorum.

5. Blatherwick, N. R., J. Biol. Chem., 1921, xlix, 193. Observations on Blood Fat in Diabetes.

6. Marsh, P. L. and Waller, H. G., Arch Int. Med..1923, xxxi, 63. The Relation between Ingested Fat and the Lipemia of Diabetes Mellitus. 